\title{
Wheat Breeding for Disease Resistance: Review
}

\section{Gadisa Alemu*}

Kulumsa Agricultural Research Center, Ethiopia

*Corresponding author: Gadisa Alemu, National Wheat Research Program, Kulumsa Agricultural Research Center, Assela, Ethiopia, Email: gadalemu@gmail.com

\section{Mini Review}

Volume 4 Issue 2

Received Date: March 19, 2019

Published Date: April 12, 2019

DOI: $10.23880 /$ oajmb-16000142

\section{Abstract}

Breeding for disease resistance is a central focus of plant breeding programs, as any successful variety must have the complete package of high yield, disease resistance, agronomic performance, and end-use quality. Wheat breeding is focused on high yield, pathogen resistance and abiotic stress tolerance. Among diseases of wheat yellow rust, stem rust, and leaf rust are the most damaging diseases of wheat and other small grain cereals. Disease resistance in wheat breeding with one exception, the diseases of wheat that is important because of their effect on yield. Resistance to all diseases together can is important to avoid an unexpected loss in effectiveness of the resistance of a cultivar to a major disease. The genetic resistance to stem rust, leaf rust and yellow rust can be characterized as qualitative and quantitative resistances. Vertical resistance is specific to pathogen isolates based on single or very few genes. Race-specific is used to describe resistance that interacts differentially with pathogen races. Quantitative resistance is defined as resistance that varies in continuous way between the various phenotypes of the host population, from almost imperceptible to quite strong. With the need to accelerate the development of improved varieties, genomics-assisted breeding is becoming an important tool in breeding programs. With marker-assisted selection, there has been success in breeding for disease resistance. Generally, breeding programs have successfully implemented molecular markers to assist in the development of cultivars with stem, leaf and stripe rust resistance genes. When new rust resistance genes are to be deployed in wheat breeding programs, it unfortunately takes several years before the new sources of resistance will become available in commercial wheat cultivars. This is due to the long process involved in the establishment of pure breeding wheat lines. Biotechnology based techniques are available to accelerate the breeding process via doubled haploid production.

Keywords: Disease Resistance; Qualitative Resistance; Quantitative Resistance and Wheat Breeding

\section{Introduction}

Bread wheat (Triticum aestivum. $L$ ) belongs to family gramineae and is the major staple food crop of the world. It is believed that bread wheat originated in south western Asia from where it spread to other parts of Asia, Europe, Africa and America [1]. Bread wheat is the largest cereal crop extensively grown as staple food sources in the world [2]. It is one of the most important export and strategic cereal crop in the world and in Ethiopia in terms of production and utilization [3].

Wheat is one of the most important and significant cereal staple food crops in the world, both in terms of food production and for providing the total amount of food calories and protein in the human diet [4]. However, wheat production is constrained by various wheat diseases caused by fungal, bacterial, and viral pathogens. 


\section{Open Access Journal of Microbiology \& Biotechnology}

Wheat breeding is focused on high yield, pathogen resistance and abiotic stress tolerance. Among diseases of wheat yellow rust, stem rust and leaf rust are the most damaging diseases of wheat and other small grain cereals. Historically, yellow rust has caused and is presently causing significant and severe losses on susceptible wheat cultivars worldwide [5]. Moreover, the recent detection of the widely virulent race Ug99 in Uganda in 1998 challenged the misconception that stem rust was a conquered disease [6]. Now, up to $90 \%$ of world's wheat cultivars are considered stem rust susceptible and the disease is threatening 120 million tons or $20 \%$ of the world's wheat in Central and North Africa, the Middle East and Asia, with a population of more than one billion people $[7,8]$.

Disease resistance is often defined as reduction of pathogen growth on or in the plant [9]. It denotes less disease development in a genotype than that in the susceptible variety and is a relative attribute. Generally, the rate of reproduction is considerably reduced which limits the spread of disease. Plants are almost always resistant to certain pathogens but susceptible to other pathogens; resistance is usually pathogen species-specific or pathogen strain-specific [9]. Breeding for disease resistance in wheat has a long and largely successful history [10]. A high standard of disease control, involving the development and use of effective systemic fungicides alongside adequate genetic resistance to most diseases in most cultivars, has made a major contribution to reliably high yields of wheat history [10]. The challenge of maintaining and even increasing this yield gain means that the interaction between selection for disease resistance on the one hand and selection for plant adaptation and productivity, resulting in improved yield and quality, on the other should be well understood history [10].

Disease resistance in wheat breeding with one exception, the diseases of wheat that is important because of their effect on yield. Resistance to all diseases together can is important to avoid an unexpected loss in effectiveness of the resistance of a cultivar to a major disease. Such 'breakdowns' of resistance, caused by evolution of virulence (the loss of virulence) in the pathogen [11].

Breeding programs have successfully implemented molecular markers to assist in the development of cultivars with stem, leaf and stripe rust resistance genes. When new rust resistance genes are to be deployed in wheat breeding programs, it unfortunately takes several years before the new sources of resistance will become available in commercial wheat cultivars. This is due to the long process involved in the establishment of pure breeding wheat lines. Biotechnology based techniques are available to accelerate the breeding process via doubled haploid production.

Wheat breeding for disease resistance is linked with common farming systems aimed at obtaining high productivity and quality of products. Growing of susceptible cultivars that will require many pesticide applications is not undoubtedly cost effective and, besides, it is also too risky due to toxic residues. Breeding for multiple resistance to diseases has become the promising breeding strategy.

The aim of modern resistance breeding is to obtain sufficient resistance to all most important diseases rather than high resistance to one disease only, while the cost of resistance is also considered. The research linked with breeding is oriented towards the detection of resistance sources usable as prospective parents, setting of new methodology for resistance testing and effective application of molecular markers.

\section{Type of Disease Resistance in Wheat}

The genetic resistance to stem rust, leaf rust and yellow rust can be characterized as qualitative and quantitative resistances. The qualitative resistance is classified into race specific or vertical, seedling resistance, monogenic (major genes), hypersensitive, and the quantitative resistance is classified into the racenonspecific or horizontal, adult plant resistance, slow rusting, polygenic (minor gene), durable. Two types of rust resistance in wheat.

\section{Vertical (Qualitative) Resistance}

Vertical (qualitative, major) resistance is specific to pathogen isolates based on single or very few genes. Race-specific is used to describe resistance that interacts differentially with pathogen races; it is applied both to complete resistance and the components of incomplete resistance that so interact [12]. Vertical race specific resistance towards which the biotypes of a pathogen show obvious differences in specific virulence and which often proves temporary. Race-specific resistances are easily detected with specific pathotypes or races of the pathogen and are controlled by genes having major effects. In wheat rust pathosystems, these resistances are recognized by characteristic low infection types. Most of these genes can be detected in 


\section{Open Access Journal of Microbiology \& Biotechnology}

seedling evaluations using specific pathotypes. However, detection of a few others requires testing at post seedling growth stages. Major genes are implicitly vulnerable to pathogen plasticity, and their longevity can range from rapid vulnerability to relative (and often deceiving) durability. The gene-for-gene relationship states that for every resistance gene in the host plant there is a corresponding a virulence gene in the pathogen. However the ability of a virulent gene to mutate to a virulent gene, no longer recognizable by the corresponding resistance gene, implies a type of resistance termed race-specific resistance.

A race-specific or vertical resistance signifies that the resistance to some pathogens is relatively simply inherited. The race-specific resistance is virulent only to particular races of a pathogen. Race-specific resistance is often based on genes that are effective at the seedling stage and remain effective at all post-seedling stages of the plants. Race specific resistance is usually governed by a hypersensitive response, controlled by major genes. Hypersensitive genes work by giving the plant the ability to recognize the invading rust and trigger rapid cell death of infected cells, thereby preventing infection from establishing in the plant [13]. Since $L r$ genes that confer this ability to the plant are effective only for a specific leaf rust virulence, the term "race specific" resistance has been used for this type of resistance. The race-specific resistance is also known as monogenic resistance (resistance determined by a single gene), often led by a boom and bust cycle [12].

\section{Quantitative (Horizontal Resistance)}

Quantitative resistance is defined as resistance that varies in continuous way between the various phenotypes of the host population, from almost imperceptible (only a slight reduction in the growth of the pathogen) to quite strong (with little growth of the pathogen). Quantitative resistance occurs at various levels to nearly all important pathogens in most cultivars of the crops [14]. Its expression depends upon the genotype and environment, whereby the pathogen is part of that environment. The environment can affect the durability considerably too [12]. Incomplete or partial resistance is assumed to be under polygenic control and such resistance will be racenonspecific. This does not establish that all durable resistance is controlled by many genes, but, even where it is, this need be no deterrent to its use by plant breeders who frequently select for characters, such as yield, that are also controlled by many genes.

Race non-specific resistance conditioned by polygenes or quantitative genes is generally complex, as is its identification. Race-nonspecific resistances operate against all pathotypes or races of a pathogen. The genetic nature of this type of rust resistance is usually complex and based on the additive interaction of a few or several genes having minor to intermediate effects. Most of the race non-specific resistance tests have been carried out in adult plants.Thus, APR genes are considered to control race nonspecific resistance, thereby contributing with partial resistance and being associated with a slow rusting resistance [12].

The race non-specific resistance is governed by minor genes and is therefore considered as a polygenetic resistance (resistance to parasites based on many genes). This type of resistance is often considered as durable and the genes are pyramiding. Most commonly, race nonspecific resistance is characterized by durability, having a partially resistant phenotype, and being effective to a broad range of stem rust and yellow rust races with optimal level of expression at the adult plant stages. Racenonspecific resistances are mainly effective at the postseedling and adult plant stages and adult plant resistance (APR) is often detected as field resistance [15].

The best known APR genes in wheat are $\mathrm{Sr} 2$, a stem rust resistance gene and $\operatorname{Lr} 34$, a gene that provides resistance to leaf and stripe rust and powdery mildew. These genes have been used in commercial wheat varieties for almost 100 years. Sr2 and $\operatorname{Lr} 34$ have provided partial resistance for many years over large areas and under high and prolonged disease pressure in the field, hence they have proven durable. To further compound the situation, in addition to overcoming $S r 31$, Ug99 had a very wide spectrum of virulence toward most of the other commonly used R genes and rapidly evolved virulence to the important R genes, $S r 24$ and $\operatorname{Sr} 36$, which has hampered the initial emergency breeding response to incorporate resistance to this strain [7].

Slow rusting is a type of resistance where disease progresses at a retarded rate, resulting in intermediate to low disease levels against all pathotypes of a pathogen. It also called partial resistance referring to leaf rust resistance in barley, is a form of incomplete resistance characterized by a reduced rate of epidemic development despite a high or susceptible infection type. The components that cause slow rusting of a cultivar are longer latent period, low receptivity or infection frequency, as well as smaller uredial size and reduced duration and quantity of spore production. The stem rust resistance gene $\mathrm{Sr} 2$ is considered to be one example of a gene contributing to partial or slow rusting resistance [16]. 


\section{Open Access Journal of Microbiology \& Biotechnology}

\section{Methods of Wheat Breeding for Disease Resistance}

Breeding for disease resistance is a central focus of plant breeding programs, as any successful variety must have the complete package of high yield, disease resistance, agronomic performance, and end-use quality. With the need to accelerate the development of improved varieties, genomics-assisted breeding is becoming an important tool in breeding programs. With markerassisted selection, there has been success in breeding for disease resistance; however, much of this work and research has focused on identifying, mapping, and selecting for major resistance genes that tend to be highly effective but vulnerable to breakdown with rapid changes in pathogen races [17]. In contrast, breeding for minorgene quantitative resistance tends to produce more durable varieties but is a more challenging breeding objective. As the genetic architecture of resistance shifts from single major $\mathrm{R}$ genes to a diffused architecture of many minor genes, the best approach for molecular breeding will shift from marker-assisted selection to genomic selection [17]. Genomics assisted breeding for quantitative resistance will therefore necessitate whole genome prediction models and selection methodology as implemented for classical complex traits such as yield [17].

Breeding is carried out either by conventional breeding techniques described earlier or by mutation breeding. The conventional method of breeding for disease resistance is back crossing and screening.

\section{Back Cross Methods}

Matthew Robbins reported that the backcross breeding approach can be employed to introduce a specific trait, such as disease resistance, from one line, often an unimproved line, to another line that is typically an elite breeding line [18]. Backcross breeding is an effective method to transfer one or a few genes controlling a specific trait from one line into a second usually elite breeding line. The parent with the desired trait called the donor parent, provides the desired trait and may not perform as well as an elite variety in other areas. The elite line, called the recurrent parent, usually performs well in all other areas. Backcrossing involves making an initial cross between the donor and recurrent parents. The resultant $\mathrm{F}_{1}$ progeny have $50 \%$ of their genetic material from each parent. $F_{1}$ individuals are crossed to the recurrent parent to develop a backcross one $\left(\mathrm{BC}_{1}\right)$ population. Individuals from the $\mathrm{BC}_{1}$ population are once again crossed to the recurrent parent. Each generation of backcrossing reduces the proportion of the donor parent present in the population by half [18]. This cycle of crossing backcross progeny to the recurrent parent continues until a new line that is identical to the recurrent parent, but with the desired gene or trait from the donor parent is created. $\mathrm{By}$ the $\mathrm{BC}_{4}$ generation, the lines are $>96 \%$ identical to the recurrent parent. Crossing of a desirable but disease susceptible plant variety to another variety that is a source of resistance, to generate plant populations that mix and segregate for the traits of the parents.

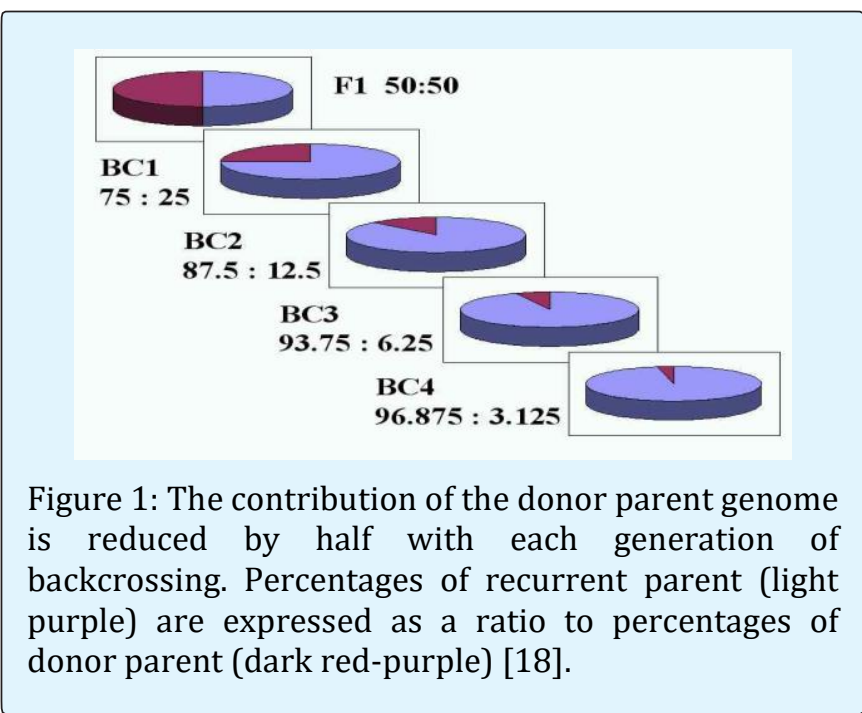

\section{Screening}

Screening germplasm for resistance sources, hybridization of selected parents, selection and evaluation of hybrids and testing and release of new varieties. This may require artificial epidemics created by inoculation of pathogen onto the plant population.

The probability of identifying resistant parents and resistant progenies is increased by the availability of a reliable screening methodology and an environment favorable for disease development. Depending on the disease and choice of the type of resistance, the methodology may require simple tests in the greenhouse on seedlings or adult plants, replicated field tests, or even the use of resistance-linked protein and DNA markers. Protocols for screening for resistance to most diseases are well established and can be employed in breeding for resistance. Inclusion of check cultivars for resistance and susceptibility is important to assess the disease pressure and degree of resistance. Choice of field sites with reliable environmental conditions is crucial for progress when selection is to be carried out in field conditions. The 


\section{Open Access Journal of Microbiology \& Biotechnology}

wheat breeding programme in Mexico shuttles the segregating populations between sites in Mexico, or sites between Mexico and hotspot locations outside Mexico, to select multiple disease resistances.

\section{Wheat Breeding for Disease Resistance}

Since, new races of yellow rust and stem rust are moving and spreading throughout the world wide wheat production regions, identification and transfer of novel sources of resistance genes are necessary. A number of wheat lines with transferred genetic material from related species are available such as wheat-rye, wheat leymus and wheat thinopyrum translocations/substitutions. The incorporation of genetic material from related species leads to wheat varieties adapted to the environment of interest, and to greater sustainability of the wheat production. Breeding can change the importance of diseases those that were defeated by resistance breeding are superseded by other diseases.

\section{Stem Rust}

Stem rust caused by Puccinia graminis Pers. f. sp. tritici Eriks. \& E Henn. (Pgt) is one of the major and economically important diseases of wheat in Ethiopia. Host resistance is the most effective, and economically and environmentally friendly method of disease control. An effective deployment of resistance genes for the management of stem rust in wheat requires knowledge about the resistance status and the diversity of resistance genes in cultivars under consideration. Although wheat lines released by the CIMMYT programme are selected based on their stem rust resistance it is essential to have data on the local pathotypes, and it is even greater advantage to know the actual genes responsible for resistance in each cultivar [6]. The national breeding programme undertakes multi location tests in hot spot areas to determine the resistance level of newly developed wheat cultivars to stem rust and other diseases.

Variants with virulence for Sr24 and Sr36 genes were detected in Kenya. Similarly, virulence to SrTmp gene was detected from stem rust samples collected during the 2013 season epidemics that wiped out Digalu in Bale zone of Ethiopia. However, the race responsible for the loss of effectiveness of SrTmp gene in Digalu was reported in Turkey prior to its discovery in Ethiopia [19-22].

Currently, race Ug99 (TTKSK) is continuously evolving and undergoing stepwise mutations, to bear additional virulence. There are 10 variants of this race reported across many parts of Africa [23] and its migration and spread to other parts of Africa, Asia and other parts of the world is inevitable [7].

In view of the recurrent epidemics of stem rust in eastern Africa, an internationally aggressive breeding strategy was followed and resistant cultivars were released in countries most vulnerable to this race. For instance, in Kenya two bread wheat cultivars, Eagle-10 and Robin, were released in 2009 and in Ethiopia, Kakaba and Danda'a were released in 2010 as resistant cultivars to Ug99 [24].

Resistance to stem rust is a high priority in spring wheat (Triticum aestivum. L.) breeding programs. Stem rust resistance in current bread eventually may be threatened by the introduction of a new virulent race. Introduction of other stem rust races with virulence to commonly grown spring wheat's may occur. Identification of stem rust resistance genes in current cultivars will facilitate incorporation of additional effective genes into breeding programs.

\begin{tabular}{|c|c|c|c|}
\hline \multirow{2}{*}{ No } & \multirow{2}{*}{ Reaction category } & \multicolumn{2}{|c|}{ Number of line } \\
\cline { 3 - 4 } & & Arsi Robe & Njoro \\
\hline 1 & 0 & 10 & 0 \\
\hline 2 & R & 11 & 4 \\
\hline 3 & RMR & 5 & 12 \\
\hline 4 & MR & 29 & 91 \\
\hline 5 & M & 79 & 150 \\
\hline 6 & MS & 31 & 24 \\
\hline 7 & MS & 45 & 16 \\
\hline 8 & S & 96 & 9 \\
\hline
\end{tabular}

Where: $\mathrm{R}=$ resistant, $\mathrm{RMR}=$ resistant to moderately resistant, $\mathrm{MR}=$ moderately resistant, $\mathrm{M}=$ moderately resistant to moderately susceptible, $\mathrm{MS}=$ moderately susceptible, MSS=moderately susceptible to susceptible and $S=$ susceptibl, Source: Worku, et al. [25].

Table 2: Number of elite bread wheat line in resistant and susceptibility categories in Ethiopia and Kenya

\section{Yellow Rust}

Stripe rust, caused by Puccinia striiformis f. sp. tritici (Pst), is one of the most serious diseases of wheat, and has been reported in more than 60 countries [26]. It is the most destructive disease in northwest and southwest China [27]. Over recent years, the disease has become increasingly important in a number wheat-growing areas, such as South Africa the central states of the United States 


\section{Open Access Journal of Microbiology \& Biotechnology}

of America [28] and western Australia [29]. Growing resistant cultivars is the most effective and environmentally safe way to reduce yield losses. To date, more than 70 stripe rust resistance genes, officially or provisionally designated Yr for 'stripe rust', reported in wheat $[26,30]$. Most of these genes are race-specific and confer all-stage resistance, which can be detected at the seedling stage, but a few are expressed only at the growth stage [26].

Recently virulence to $\operatorname{Yr} 17$, an as yet important gene in western European cultivars, is spreading. The resistance of some cultivars, of Chappelle Desprez, is more durable. Field resistance has been found to be considerably durable and effective. Yellow rust can play a very important role particularly in colder regions. The last epidemic of yellow rust was in the years around 2000, since that time its incidence has been low.

The germplasm of wheat (about 1200 accessions) was screened under artificial inoculation with mixture of races and the parents having partial resistance for $\mathrm{Yr}$ were selected. This germplasm was crossed to pyramid genes for high yield and rust resistance. The main focus was accumulation of minor genes for Yr resistance because this type of resistance mechanism is considered more durable and is effective for many races rather than single race. The resistance parents is selected from screened wheat line.

\section{Leaf Rust}

Leaf rust (Puccinia triticina Eriks.) is an important disease of wheat that is most economically controlled by breeding for resistance. Due to the large number of different pathotypes of leaf rust, resistance breeding is a continuous process. Knowledge of virulence in the leaf rust population is a prerequisite for successful resistance breeding.

Leaf rust has been an important disease of wheat in most wheat growing areas of Ethiopia [31]. It is the most prevalent type of rust, which causes yield losses up to $70 \%$ on susceptible cultivars [32]. The best alternative to reduce loss from such a disease would be to use resistant cultivars Wheat varieties relying on race-specific resistance often lose effectiveness within a few years by imposing selection for virulent leaf rust races $[13,32]$. Due to non-durability of resistance in cultivars that contain only specific major genes for resistance, recent breeding programs have focused on developing cultivars with adult plant resistance or slow rusting. Slow rusting resistance is a type of resistance that is both race non-specific and durable [12]. It is polygenic and effective against a broad range of leaf rust races [33]. Slow rusting resistance is characterized by a slow epidemic build up despite a high infection type indicating a compatible host-pathogen relationship [12]. In wheat only a small group of leaf rust resistance genes are known as slow rusting genes such as Lr67 ,Lr34, Lr46 and Lr68 [33].

\begin{tabular}{|c|c|c|c|}
\hline Phenotype class & Line Tested & Parent of Lr34 markers & Percentage with Lr34 \\
\hline Race Specific & 71 & 27 & $38 \%$ \\
\hline Race Nonspecific & 94 & 43 & $46 \%$ \\
\hline Defeated Race Specific & 5 & 1 & $20 \%$ \\
\hline Susceptible & 22 & 10 & $45 \%$ \\
\hline
\end{tabular}

Christopher Andrew Thomas [34].

Table 4: Lr34 marker resulted grouped by phenotype class.

\begin{tabular}{|c|c|c|c|c|}
\hline Level of susceptibility & Number of race nonspecific gene & Lr34(+) & Lines & Percentage of line \\
\hline Trace to 20MS & 4 to 5 & No & 42 & $40 \%$ \\
\hline 20MS to 30MS & 2 to 3 & No & 8 & $8 \%$ \\
\hline 30MS or higher & 0 to 1 & No & 0 & $0 \%$ \\
\hline Trace to 5MS & 3 to 4 & Yes & 3 & $3 \%$ \\
\hline 5MS to 20MS & 2 to 3 & Yes & 33 & $32 \%$ \\
\hline 20MS to 30MS & 1 to 2 & Yes & 7 & $7 \%$ \\
\hline 30MS to 50S & 1 & Yes & 11 & $11 \%$ \\
\hline
\end{tabular}

Christopher Andrew Thomas [34].

Table 5: Number of race nonspecific gene postulated in line analyzed with Lr 34 Marker. 
Resistance breeding in the world was particularly successful when partial, field or adult plant resistance was exploited. An example is the gene Lr34 in the CIMMYT wheat breeding, linked with $\operatorname{Yr} 18$, Byd1 and Ltn. Leaf tip necrosis can be utilized as a marker for $\operatorname{Lr} 34$.

Disease resistance genes, transferred from wild species, support wheat production on a global level [35]. More than 80 genes and alleles of leaf rust resistance $(L r)$ genes have been identified and described so far. Among them $33 \mathrm{Lr}$-genes were transferred from other species into Triticum aestivum L [36]. Most of them are racespecific and follow the gene-for-gene concept. The resistance, based on such single gene, is overcome by pathogen in a short time. Virulent pathotypes emerge in a population via changes in pathogen's genome (sexual recombination or mutation). In contrast, non-specific genes do not confer high level of resistance but due to the slow rusting effect prevent epiphytoty of disease and provide longtime resistance. To date, there are known four loci which contain $L r$-genes designated as $L r 34, L r 46$, Lr67 and $L r 68$ that provide race non-specific, adult plant resistance (APR) [37]. Combining them in one genotype with race-specific genes ensures more durable resistance than that based on single seedling resistance genes. The most widely and successfully applied gene is Lr34, which may enhance resistance of the other seedling genes and has positive pleiotropic effect against other wheat diseases [38].
Checking of effectiveness of known Lr-genes in single use and in different combinations, continuous virulence analysis of wheat leaf rust and transferring new genes from wild species to wheat pool are important strategies for wheat improvement. It has been established that wild species A. tauschii and A. cylindrica carry in their Dgenome genes of resistance - Lr21, Lr22a, Lr32, Lr39 and Lr42, T. dicoccoides - gene Lr53 (B genome) [36]. Gene Lr34 is present in greater part of bread wheat cultivars in PBGI-NC SCI [39].

The developed breeding lines have high resistance against the majority of bread wheat diseases, including leaf rust, widely distributed in the south of Ukraine $[40,41]$. Applying backcross and selection methods on artificially infected nurseries a range of wheat breeding lines possessing resistance to the main wheat diseases, including leaf rust, was developed [40].

The investigated breeding lines carried genes $\operatorname{Lr} 21$, Lr24, Lr34 and T1AL.1RS. As was reported, the gene Lr21 was derived from A. tauschii [36]. The results indicate that T. erebuni also carried Lr21. We suppose that $L r 21$ could be transferred in breeding lines from species which have D-genome (A. tauschii, A. cylindrica or T. erebuni), translocations T1BL.1BS-3Ae\#1L (Lr24) and T1AL.1RS were transferred from cv. 'Amigo', non-specific gene Lr34 was transferred from recurrent cultivars.

\begin{tabular}{|c|c|c|}
\hline Approximate degree of susceptibility & Number of race non susceptibility & Presence of Lr34 \\
\hline $10 \%$ & 4 to 5 & No \\
\hline $30 \%$ & 2 to 3 & No \\
\hline $100 \%$ & 0 & No \\
\hline $1-5 \%$ & 3 to 4 & Yes \\
\hline $10-15 \%$ & 2 to 3 & Yes \\
\hline $40 \%$ & 1 & Yes \\
\hline
\end{tabular}

Source: Singh, et al. [7].

Table 6: Change in degree of susceptibility to leaf rust as more race nonspecific gene are incorporated into lines, with and without Lr34.

\section{Conclusion}

Wheat is one of the most important and significant cereal staple food crops in the world, both in terms of food production and for providing the total amount of food calories and protein in the human diet. However, wheat production is constrained by various wheat diseases caused by fungal, bacterial, and viral pathogens.

Wheat breeding is focused on high yield, pathogen resistance and abiotic stress tolerance. Among diseases of wheat yellow rust, stem rust, and leaf rust are the most damaging diseases of wheat and other small grain cereals. Disease resistance in wheat breeding with one exception, the diseases of wheat that are important because of their effect on yield. Resistance to all diseases together can is important to avoid an unexpected loss in effectiveness of the resistance of a cultivar to a major disease.

The genetic resistance to stem rust, leaf rust and yellow rust can be characterized as qualitative and quantitative resistances. Vertical (qualitative, major) 


\section{Open Access Journal of Microbiology \& Biotechnology}

resistance is specific to pathogen isolates based on single or very few genes. Race-specific is used to describe resistance that interacts differentially with pathogen races. Quantitative resistance is defined as resistance that varies in continuous way between the various phenotypes of the host population, from almost imperceptible to quite strong (with little growth of the pathogen) [42-44].

Breeding for disease resistance is a central focus of plant breeding programs, as any successful variety must have the complete package of high yield, disease resistance, agronomic performance, and end-use quality. With the need to accelerate the development of improved varieties, genomics-assisted breeding is becoming an important tool in breeding programs. With markerassisted selection, there has been success in breeding for disease resistance. Generally, breeding programs have successfully implemented molecular markers to assist in the development of cultivars with stem, leaf and stripe rust resistance genes. When new rust resistance genes are to be deployed in wheat breeding programs, it unfortunately takes several years before the new sources of resistance will become available in commercial wheat cultivars. This is due to the long process involved in the establishment of pure breeding wheat lines. Biotechnology based techniques are available to accelerate the breeding process via doubled haploid production.

\section{References}

1. Bertholdsson NO (2005) Early vigor and AllelopathyTwo useful traits for enhancing barley and wheat competitiveness against weeds. Weed Research 45(2): 94-102.

2. Mollasadeghi V, Shahryari R (2011) Important morphological markers for improvement of yield in bread wheat. Advances in Environmental Biology pp: 538.

3. Ranjana, Suresh Kumar (2013) Study of genetic variability and heritability over extended dates of sowing in bread wheat (Triticum aestivumL.). Research in Plant Biology 3(1): 33-36

4. Gupta PK, Mir RR, Mohan A, Kumar J (2008) Wheat Genomics: Present Status and Future Prospects. Int J Plant Genomics

5. Wellings CR (2011) Global status of stripe rust: a review of historical and current threats. Euphytica 179(1): 129-141
6. Singh RP, Hodson DP, Espino HJ, Jin Y, Njau P, et al. (2008) Will stem rust destroy the world's wheat crop? Advances in Agronomy 98: 271-309.

7. Singh RP, Hodson DP, Espino J, Yue Jin, Bhavani S (2011) The 61 Emergence of Ug99 Races of the Stem Rust Fungus is a Threat to World Wheat Production. Annu Rev Phytopathol 49: 465-481.

8. Dixon J, Braun HJ, Kosina P Crouch J (2009) Wheat Facts and Futures 2009. Mexico, D.F: CIMMYT, pp: 95.

9. Nabi S, Devendra K (2015) Breeding for Disease Resistance. PhD Scholars, Division of plant pathology IARI New Delhi 110012, 14(06) 83-84.

10. Summersa RW, Brown JKM (2013) Constraints on breeding for disease resistance in commercially competitive wheat cultivars. Plant Pathology 62 (51): 115-121.

11. Brown JKM, Hovmøller MS (2002) Aerial dispersal of fungi on the global and continental scales and its impact on plant disease. Science 297(5581): 537-541.

12. Priyamvada MS, Saharan, Tiwari R (2011) Durable resistance in wheat. International Journal of Genetics and Molecular Biology 3(8): 108-114.

13. Bolton MD, JA Kolmer DF, Garvin (2008) Wheat leaf rust caused by Puccinia triticina. Mol Plant Pathol 9(5): 563-575.

14. Xavier Ribeiro do vale FX, Parlevliet JE, Zambolim L (2001) Concepts in plant disease resistance. Fitopatologia Brasileira, 26:577-589.

15. Hovmøller SM, Sørensen CK, Walter S, Justesen FA (2011) Diversity of Puccinia striiformis on Cereals and Grasses. Annu Rev Phytopathol 49: 197-217.

16. Bansal UK, Bossolini E, Miah H, Keller B, Park RF, et al. (2008) Genetic mapping of seedling and adult plant stem rust resistance in two European winter wheat cultivars. Euphytica 164(3): 821-828.

17. Poland J, Rutkosk J (2016) Advances and Challenges in Genomic Selection for Disease Resistance. Annual Review of Phytopathology 54: 79-98.

18. Robbins M (2012) Backcrossing, Backcross (BC) Populations, and Backcross Breeding.

19. Jin Y, Szabo LJ, Pretorius ZA, Singh RP, Ward R, et al. (2008) Detection of virulence to resistance gene Sr24 


\section{Open Access Journal of Microbiology \& Biotechnology}

within race TTKS of Puccinia graminis $\mathrm{f}$. sp. tritici. Plant Dis 92(6): 923-926.

20. Jin Y, Szabo LJ, Rouse MN, Fetch TJR, Pretorious ZA, et al. (2009) Detection of virulence to resistance gene Sr36 within the TTKS race lineage of Puccinia graminis f.sp. tritici. Plant Disease 93(4): 367-370.

21. Olivera PD, Newcomb M, Szabo LJ, Rouse MN, Johnson J, et al. (2015) Phenotypic and genotypic characterization of race TKTTF of Puccinia graminis $\mathrm{f}$. sp. tritici that caused a wheat stem rust epidemic in southern Ethiopiain 2013-14. Phytopathology 105(7): 917-928.

22. Zafer M, Aziz K, Fazyl D, Kadir A, Lutfi, C (2012) Determination of Puccinia graminis f. sp. tritici races of wheat in Turkey. Turkish Journal Agriculture and Forestry 36: 107-120.

23. Singh RP, Hodson DP, Jin Y, Lagudah ES, Ayliffe MA, et al. (2015) Emergence and spread of new races of wheat stem rust fungus: Continued threat to food security and prospects of genetic control. Phytopathology 105(7): 872-884.

24. Njau PN, Wanyera R, Singh D, Singh R, Gethi, M (2011) Release of stem rust resistant wheat varieties for commercial production in Kenya. Journal of Agricultural Science and Technology A1: 587-598.

25. Worku W, Zerihun T, Daniel K, Habtemariam Z, Dawit A (2016) Development of wheat germplasm for stem rust resistance in eastern Africa. African Crop Science Journal 24(1).

26. Chen XM (2005) Epidemiology and control of stripe rust on wheat. Canadian Journal of Plant Pathology 27(3): 314-337.

27. Wan AM, Zhao ZH, Chen XM, He ZH, Jin SL, et al. (2004) Wheat stripe rust epidemic and virulence of Puccinia striiformis f. sp. tritici in China in 2002. Plant Disease 88(8): 896.

28. Chen XM, Moore M, Milus EA, Long D, Marshall D, et al. (2002) Wheat stripe rust epidemics and races of Puccinia striiformis f. sp. tritici in the United States in 2000. Plant Disease 86(1): 39.

29. Wellings CR, Wright DG, Keiper F, Loughman R (2003) First detection of wheat stripe rust in Western Australia: evidence for a foreign incursion. Australia Plant Pathology 32(2): 321-322.
30. Cheng P, Chen XM (2010) Molecular mapping of a gene for stripe rust resistance in spring wheat cultivar ID0377s. Theor Appl Genet 121(1): 195-204.

31. Badebo A, Eshetu B, Berhanu B, Bekele H, Melaku D (2008) Review of two decades of research on diseases of small cereal crops. Proceedings of the $14^{\text {th }}$ Annual Conference of the Plant Protection Society of Ethiopia (PPSE), December 19-22, 2006, Addis Ababa, Ethiopia, pp: 375-429.

32. Draz IS, Elseoud AMS, Kamara AM, Eldein AOA, Bebany EAF (2015) Screening of wheat genotypes for leaf rust resistance along with grain yield. Ann Agric Sci 60(1): 29-39.

33. Foessel HSA, Singh RP, Espino HJ, Crossa J, Djurle AJ (2007) Evaluation of slow rusting resistance components to leaf rust in CIMMYT durum wheats. Euphytica 155(3): 361-369.

34. Christopher, Thomas A (2012) evaluating lines in a wheat breeding program for race nonspecific resistance to leaf rust, puccinia triticina. Bachelor of Science/Botany Bachelor of Science/Biochemistry University of Oklahoma Norman, Oklahoma.

35. Davoyan RO, Bebyakina IV, Davoyan OR, Zinchenko AN, Davoyan ER, et al. (2011) The use of synthetic forms in preservation and exploitation of the gene pool of wild common wheat relatives. Russian Journal of Genetics: Applied Research 2(6): 480-485.

36. Catalogue of gene symbols for wheat (2012) In. McIntosh RA, et al. by Devos KOMUGI Wheat Genetic Resource Database.

37. Silva DPR, Brammer SP, Guerra D, Milach SCK, Barcellos AL (2012) Monosomic and molecular mapping of adult plant leaf rust resistance genes in the Brazilian wheat cultivar Toropi. Genetics and Molecular Research 11 (3): 2823-2834.

38. Dakouri A, Callum MBD, Radovanovic N, Cloutier S (2013) Molecular and phenotypic Characterization of seedling and adult plant leaf rust resistance in a world wheat collection. Mol Breed 32: 663-677.

39. Galaev 0, Sivolap YU (2012) Detection of Lr34/Yr18/Pm38 locus in the varieties of soft wheat. The international scientific conference Breeding and Genetics of Agricultural Crops: Traditions and Prospects. Odessa, Ukraine, pp: 233-234. 
40. Babayants OV (2011) Immunological characteristic of wheat plant resources and verification of genetic protection against pathogens of fungal aetiology in the Steppe region of Ukraine: doctoral thesis. Plant Breeding and Genetics Institute. Kyiv, Ukraine.

41. Babayants OV, Babayants LT, Gorash AF, Vasiliev AA, Traskovetskaya VA, et al. (2012) Genetics determination of wheat resistance to Puccinia graminis f. sp. tritici deriving from Aegilops cylindrica, Triticum erebuni and Amphidiploid 4. Tsitol Genet 46 (1): 10-17.

42. Rehman AUM, Khan SH, Ahmad N (2013) Prospects of Wheat Breeding for Durable Resistance against
Brown, Yellow and Black Rust Fungi. International journal of agriculture \& biology 15(6).

43. Rane J, Pannu RK, Sohu VS, Saini RS, Mishra B, et al. (2007) Performance of yield and stability of advanced wheat genotypes under heat stress environments of the Indo-Gangetic Plains. Crop Sci. 47(4): 1561-1573.

44. Singh RP, David P, Hodson, Jin Y, Espino J, et al. (2006) Current status, likely migration and strategies to mitigate the threat to wheat production from race Ug99 (TTKS) of stem rust pathogen. Plant pathology 1(54): 1-13. 